Olexsandr Mazheyka, Prof., PhD tech. sci.

Central Ukrainian national technical university, Kropyvnickiy, Ukraine

Anatoliy Lutai

National technical university of Ukrain «KPI», Kyiv, Ukraine

\title{
Numerical Modeling in the Study of Ultrasonic Processing of Steel Parts of Agricultural Machinery
}

The priority is given to carrying out studies to improve the performance characteristics of agricultural machinery parts in the context of modern technologies. The value of ultrasonic effects for the surface treatment of steel parts is established. The relevance of research is determined. The analysis of literature sources is carried out, the necessity of optimization of technological parameters of mechanical processing of materials with use of ultrasonic influence is shown. It is established that, mechanical processes that occur during the interaction of an ultrasonic working tool and the surface of a part are rather complicated.

The expediency of studying specific aspects of the behavior of the machined material of parts on the basis of numerical modeling is determined. A model contact problem was formulated to study the processes of surface hardening during plastic deformation using ultrasound. The research tasks, boundary conditions are determined. Numerical simulation is carried out and ways of optimization of parameters of the considered technological process are described. The boundary value problem of the equation of motion, the Cauchy relation, the physical relationships of the components of the deformation components with the necessary boundary conditions are solved. As indirect characteristics, allowing to judge the level of strengthening of the material, residual plastic deformations were taken in the direction of the general axis of symmetry of the cylinder and the indenter.

The relationship between the radius of the indenter and its load is established to achieve qualitative indices of the process of ultrasonic action. The state of the surface of steel parts by parameters of microhardness and structural components is studied.

It is proved that ultrasonic treatment of agricultural machinery parts allows to increase microhardness of steel surfaces up to $27 \%$. It is established that by changing the parameters of power and ultrasonic load, it is possible to control the formation of a hardened layer in the material.

numerical modeling, detail, influence, cylinder, theory, ultrasound, deformation, stress tensor, fatigue resistance, steel, indentor, microhardness

Одержано (Received) 05.06.2018

\section{УДК 621.9.048.4}

В.І. Носуленко, проф., д-р техн. наук, В.М. Шмельов, доц., канд. техн. наук Центральноукраїнський національний технічний університет, м. Кропивницький, Україна, E-mail: shmelyovvm@gmail.com

\section{Якісні характеристики джерел тепла на сталевих електродах}

Описано згідно існуючих уявлень в області фізики теплових процесів деякі якісні характеристики джерел тепла на електродах в умовах РОД та їх відповідність експериментальним даним для електродів із заліза та сталей. Можливості та якісні і кількісні характеристики процесу РОД визначаються якісними характеристиками (якістю) джерел тепла на електродах, перш за все, об'ємною густиною теплової потужності, яка, визначається динамічним тиском потоку робочої рідини та полярністю електродів. В зв'язку з цим є можливим легко керувати якістю джерел тепла на електродах, а отже і якістю процесу ерозії, здійснюючи обробку незалежно від струму в широкому діапазоні режимів, починаючи від грубого розмірного плавлення і аж до превалюючого тонкого розмірного випаровування. електрична дуга, анод, катод, стовп дуги, джерело тепла, робоча рідина, густина струму

(C) В.І. Носуленко, В.М. Шмельов, 2018 
В.И. Носуленко, проф., д-р техн. наук, В.Н. Шмелев, доц., канд. техн. наук

Центральноукраинский национальный технический университет, г. Кропивницкий, Украина

Качественные характеристики источников тепла на стальных электродах

Описаны согласно существующих представлений в области физики тепловых процессов некоторые качественные характеристики источников тепла на электродах в условиях РОД и их соответствие экспериментальным данным для электродов из железа и сталей. Возможности и качественные и количественные характеристики процесса РОД определяются качественными характеристиками (качеством) источников тепла на электродах, прежде всего, объемной плотностью тепловой мощности, которая определяется динамическим давлением потока рабочей жидкости и полярностью электродов. В связи с этим возможно легко управлять качеством источников тепла на электродах, а следовательно и качеством процесса эрозии, осуществляя обработку независимо от тока в широком диапазоне режимов, начиная от грубого размерного плавления и до превалирующего тонкого размерного испарения.

электрическая дуга, анод, катод, столб дуги, источник тепла, рабочая жидкость, плотность тока

Постановка проблеми. Електричну дугу розглядають як суму трьох самостійно діючих джерел тепла на катоді, аноді і стовпі дуги. При цьому якісні характеристики (якість) джерела тепла на катоді визначають можливість і якісну сторону процесу ерозії (обробки) катода, а якісні характеристики (якість) джерел тепла на аноді - можливість i якісну сторону процесу ерозії (обробки) анода. Порівняльні кількісні та якісні оцінки джерел тепла на катоді і аноді, в свою чергу, дозволяють зробити висновки про полярність електричної ерозії, оскільки, як відомо, ефект електричної ерозії $\epsilon$ полярним, тобто як кількісно так і якісно ерозія катода і анода відрізняються.

Аналіз останніх досліджень і публікацій. На погляд Л. Леба [1], “надзвичайно високі концентрації енергії в катодній плямі і прилеглій до неї контрагованій плазмі роблять взагалі проблематичним для поверхні плями застосування таких понять, як робота виходу електронів, теплопровідність, температура, теплота випаровування, тиск і т. i." І. Г. Кесаєв стверджує: “Складання балансу енергії для катода при сучасному рівні знань пов'язано зі значною невизначеністю при виборі величин, що входять до нього, внаслідок чого цей метод вирішення задачі $\epsilon$ заздалегідь хибним" [2]. Треба відразу ж зазначити, що “при вивчені електричних дуг явищам біля анода приділялось значно менше уваги, ніж явищам біля катода” [1], в зв'язку з чим складання балансу енергії для анода тим більш ускладнене.

Що ж до порівняльних характеристик джерел тепла на катоді і аноді, то для звичайних дуг типа зварювальних “анодна область, на погляд більшості дослідників, має більшу довжину (висоту) та об’єм, ніж катодна. Тому концентрація енергії в цій області звичайно менша, ніж на катоді, а кумулятивні процеси при iï руйнуванні повинні в більшості випадків протікати більш мляво [1]”. Відомо також, що “анодна пляма має більшу тенденцію залишатись нерухомою, ніж катодна пляма” [3]. Крім того, якість джерел тепла на катоді $\mathrm{i}$ аноді значною мірою визначається теплофізичними константами матеріалу окремо на катоді і окремо на аноді. Так, наприклад, виявляється, що, на відміну від сталевих, тугоплавкі катоди, наприклад 3 вольфраму, руйнуються значно менш інтенсивно, ніж аноди. I, нарешті, Р. Еккер зазначає [4] “...приелектродні області відлякують експериментаторів та теоретиків великою різноманітністю форм існування... Нестачі в кількості робіт нема, недостає тільки ясності та об'єктивності."

Постановка завдання. Із викладеного можна зробити важливий, на наш погляд, висновок: скласти достовірний баланс енергії для катодної області і окремо для анодної області дуги, тобто дати кількісну і якісну характеристику джерел тепла окремо на аноді і окремо на катоді, використовуючи існуючі класичні уявлення про елементарні процеси в дузі, теперішнього часу неможливо. Тому для вивчення якості джерел тепла 
на електродах треба, принаймні зараз, використати інші засоби. Зокрема, якість джерел тепла на електродах може бути охарактеризована об'ємною густиною теплової потужності в катодному та анодному джерелах тепла [5], яка, в свою чергу, визначається густиною струму та напруженістю електричного поля відповідно в катодній та анодній областях дуги.

Виклад основного матеріалу. Густина струму в дузі, що горить в поперечному потоці рідини, нами визначена. Вона в $5 \ldots 10$ і більше разів перевищує густину струму відкритих дуг і збільшується (зменшується) при збільшенні (зменшенні) динамічного тиску потоку. При цьому напруженість електричного поля в приелектродних областях [6] в $2 \ldots 3$ рази вища, ніж у звичайних дугах в повітрі, і збільшується (зменшується) при збільшенні (зменшенні) динамічного тиску потоку. Це дозволяє зробити висновок, що при горінні дуги в поперечному потоці рідини об'ємна густина теплової потужності в катодному i анодному джерелах тепла значно вища (на порядок і більше), ніж у звичайних дугах в повітрі, і регулюється в широких межах за рахунок зміни динамічного тиску потоку; при цьому при збільшенні (зменшинні) динамічного тиску потоку об’ємна густина теплової потужності зазначених джерел тепла збільшується (зменшується). Тому така дуга, на відміну від звичайних дуг в повітрі, може бути використана для розмірної обробки металу.

Проте, в кінцевому підсумку, про придатність такої дуги для розмірної обробки металу можна судити лише за характером іiі теплової дії на електроди, зокрема по профілю лунок обробленої поверхні та по величині і структурі зон термічного впливу відповідно на катоді і аноді. Розглянемо з цією метою деякі характерні приклади.

На рис. 1 показано профілі одиничних лунок обробленої поверхні на катоді і аноді із сталі 45 при горінні дуги в поперечному потоці води при струмі $I=400 \mathrm{~A}$ і при різних динамічних тисках потоку $\boldsymbol{P}_{\boldsymbol{d}}$, а саме: a) $P_{d}=0,1 \mathrm{MПа}$; 6 ) $P_{d}=0,4 \mathrm{MПа;} \mathrm{в)}$ $P_{d}=1$ МПа. Наведені профілі лунок показують, що площі поперечних перерізів “стружки" на катоді і аноді відрізняються незначно, причому при збільшенні $\boldsymbol{P}_{\boldsymbol{d}}$ розміри “стружки” в горизонтальному напрямку зменшуються помітно, а в вертикальному напрямку - незначно. На рис. 2 для тих же умов показано зміну товщини зони термічного впливу $\boldsymbol{H}$ на катоді і аноді в функції динамічного тиску потоку $\boldsymbol{P}_{\boldsymbol{d}}$. Отримана залежність свідчить, що товщини зон термічного впливу на катоді і аноді приблизно однакові, помітно зменшуються при збільшенні $\boldsymbol{P}_{\boldsymbol{d}}$ і при достатньо значних $\boldsymbol{P}_{\boldsymbol{d}}$ практично відсутні.

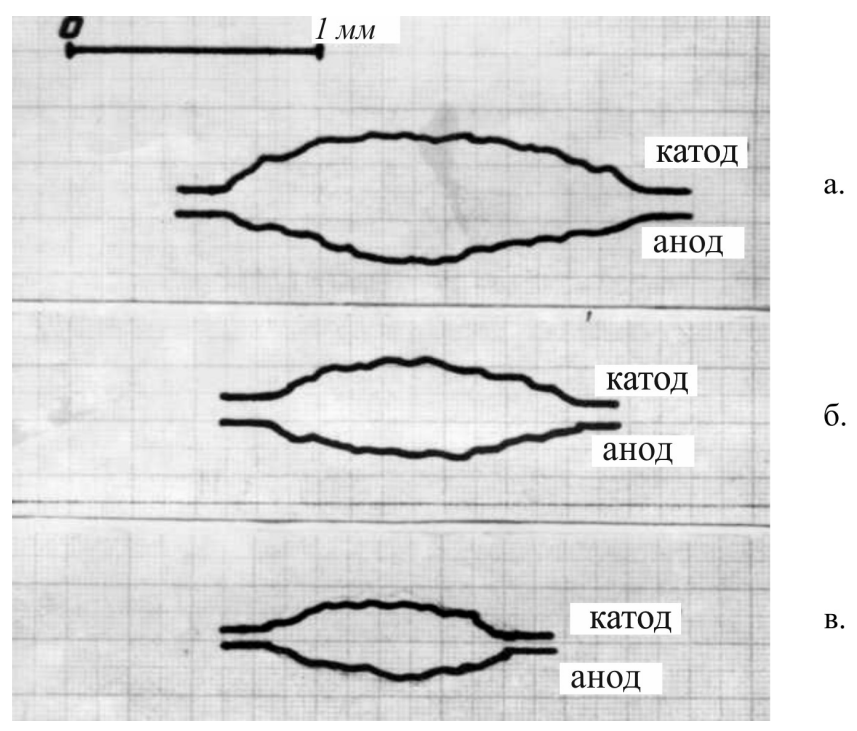

Рисунок 1 - Профілі одиничних лунок на катоді і аноді із сталі 45 


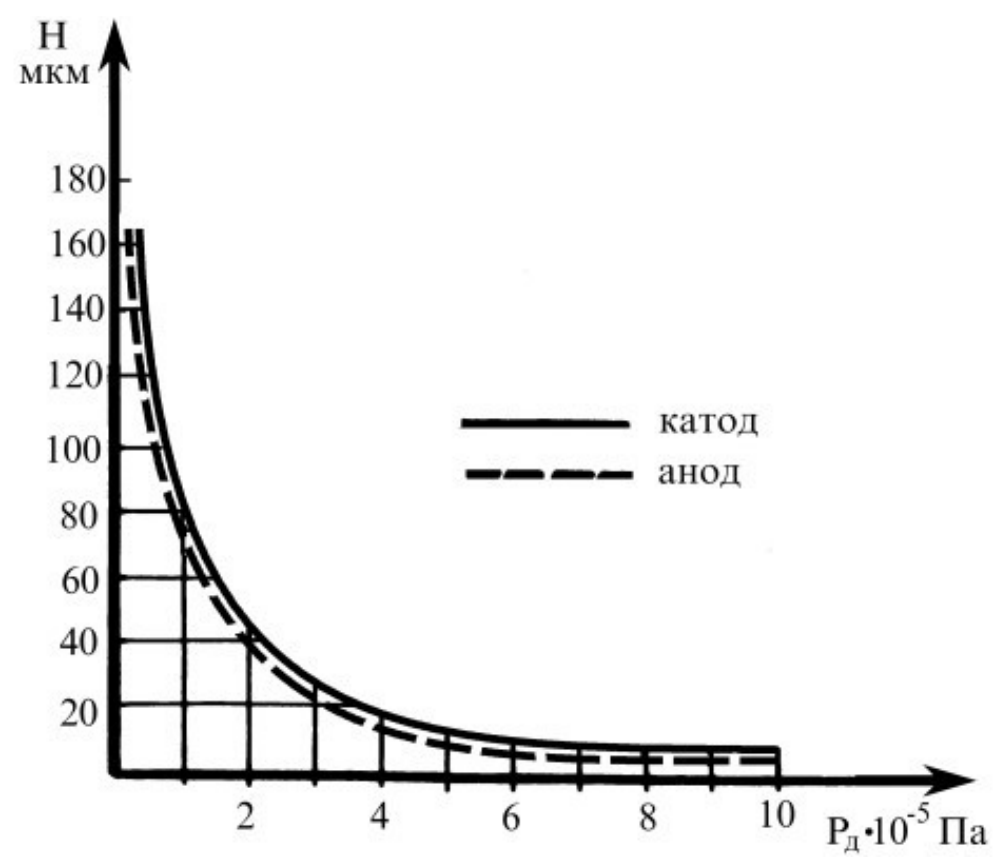

Рисунок 2 - Залежність товщини зони термічного впливу Н на катоді і аноді із сталі 45 від Pd

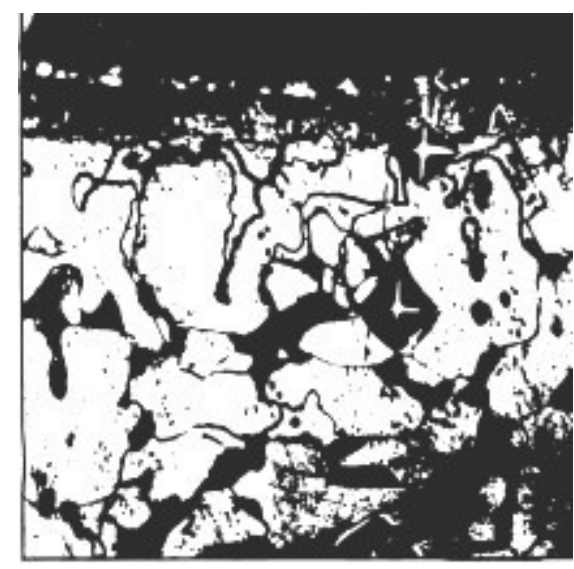

a)

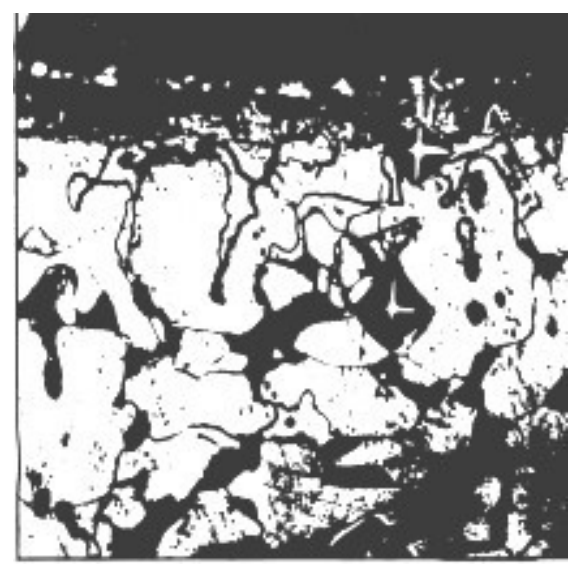

б)

Рисунок 3 - Мікроструктура зони термічного впливу на катоді (а.) і аноді (б) із сталі 45 (х500)

Зазначимо, що по структурі зони термічного впливу на катоді і аноді можуть суттєво відрізнятися. На рис. 3 показано знімки мікроструктур зон термічного впливу на катоді і на аноді для вищенаведених умов обробки при $P_{d}=0,4$ МП. На знімках видно, що зона термічного впливу на аноді не тільки дещо менша, але також не має характерного для електроерозійної обробки поверхневого шару підвищеної твердості (оскільки зерна фериту виходять до периферії шліфу), що зокрема, полегшує подальшу механічну обробку.

В діапазоні досліджених режимів обробки отримані дані дозволяють достатньо достовірно судити про якість джерел тепла на електродах, а отже про полярність електричної ерозії та технологічні режими, яким треба надати перевагу. Так, оскільки ерозовані об'єми і товщина зони термічного впливу на катоді та аноді відрізняються незначно, можна зробити висновки, що якісні та кількісні характеристики катодного і анодного джерел тепла, в відомих межах, однакові. Зменшення товщини зони термічного впливу практично до нуля при відповідному збільшенні $\boldsymbol{P}_{\boldsymbol{d}}$ дозволяє зробити висновок, що при горінні дуги в поперечному потоці рідини ерозія електродів 
може відбуватись в широкому діапазоні режимів, починаючи від розмірного плавлення і кінчаючи розмірним випаровуванням і досягається це відповідним регулюванням динамічного тиску потоку. При виборі полярності електродів та режимів обробки треба в цьому випадку враховувати конкретні технологічні задачі. Так, при необхідності подальшої механічної обробки, коли поверхневий шар підвищеної твердості небажаний, деталь повинна бути анодом (пряма полярність), а обробка повинна здійснюватись при відповідних $\boldsymbol{P}_{\boldsymbol{d}}$.

При використанні одного з електродів із сталі (Е3) і другого електрода 3 графіту (EI) якість джерела тепла на Е3, а, відповідно, кількісна та якісна сторони процесу обробки визначаються значною мірою полярністю електродів. При цьому по площі катодного джерела тепла (якщо Е3 є катод) теплова потужність розподілена достатньо рівномірно, тоді як по площі анодного джерела тепла (якщо Е3 $є$ анод) вона розподілена нерівномірно, з явно вираженим максимумом в центрі, внаслідок чого шорсткість анода значно перевищує шорсткість катода. Це видно на рис. 1, де показано профілі лунок на катоді і аноді з сталі 45 при використанні ЕI з графіту МПГ-7 при струмі $I=400 \mathrm{~A}$ і динамічному тиску потоку води $P_{d}=0,1 \mathrm{MПа.} \mathrm{Зазначимо,} \mathrm{що} \mathrm{при}$ цьому анодне джерело тепла забезпечує значно більш високу продуктивність (приблизно в 1,5...1,8 рази), ніж катодне. Тому висновок для цього випадку може бути такий: якщо треба забезпечити високу якість обробки, то слід застосовувати зворотну полярність; для забезпечення більш високої продуктивності треба застосовувати пряму полярність.

Якість джерел тепла на електродах значною мірою визначається теплофізичними константами матеріалу електродів. Зокрема, відомо, що на відміну від сталевих тугоплавкі катоди, наприклад, із твердого сплаву, руйнуються значно менш інтенсивно, ніж аноди. Тому тверді сплави в умовах РОД обробляються тільки на прямій полярності.

Треба враховувати, що якість джерел тепла на електродах може визначатись $\mathrm{i}$ бути різною в зв'язку з різними гідродинамічними режимами руху рідини по висоті міжелектродного зазору [7,8]. Це стосується перш за все ділянок, де відбувається зміна напрямку течі робочої рідини (рис. 4) [9]. Так, наприклад, при реалізації процесу поміж сталевими електродами одного діаметра при $P_{d}=0,4 \mathrm{MПа} \mathrm{при} \mathrm{відносному} \mathrm{зсуві}$ електродів - нехай навіть на десяті долі міліметра (рис. 5,a), спостерігається явно виражена нерівномірна ерозія електродів (рис. 5, б). Особливо це помітно на діаметрально протилежних ділянках. Такого не спостерігається, наприклад, при відсутності зсуву електродів або ж при звичайному прошиванні. Це означає, що визначальними в цьому випадку є різні гідродинамічні режими течі робочої рідини по висоті міжелектродного зазору, які обумовлюють різну якість джерел тепла на електродах, а отже різні кількісні та якісні характеристики процесу ерозії електродів. Отримує пояснення також факт інверсії електричної ерозії.

Визначимо згідно існуючих уявлень в області фізики теплових процесів деякі якісні характеристики джерел тепла на електродах в умовах РОД та їх відповідність експериментальним даним для електродів із заліза та сталей. 


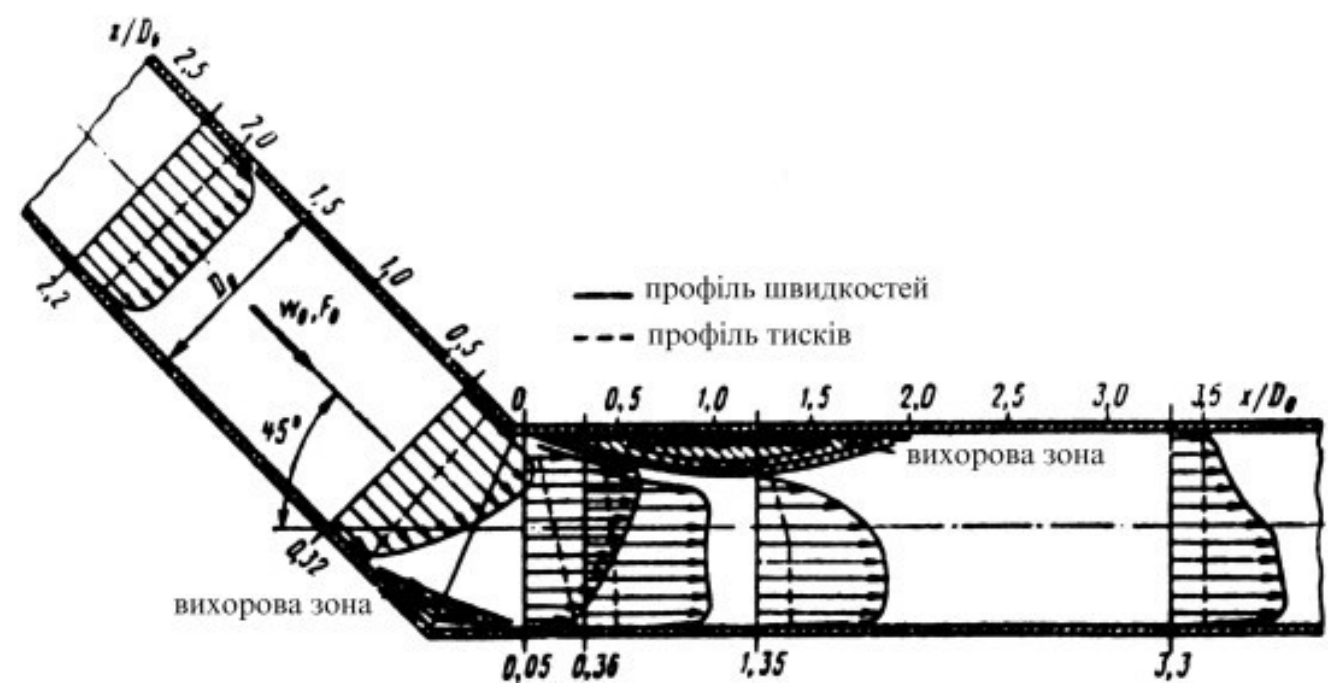

Рисунок 4 - Епюра швидкостей і тисків потоку рідини в вигнутих каналах

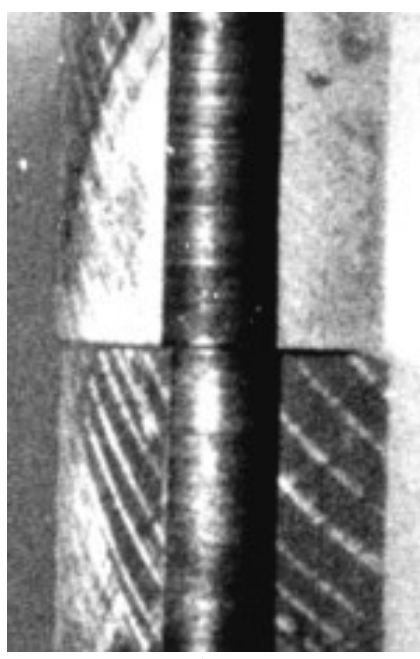

a)

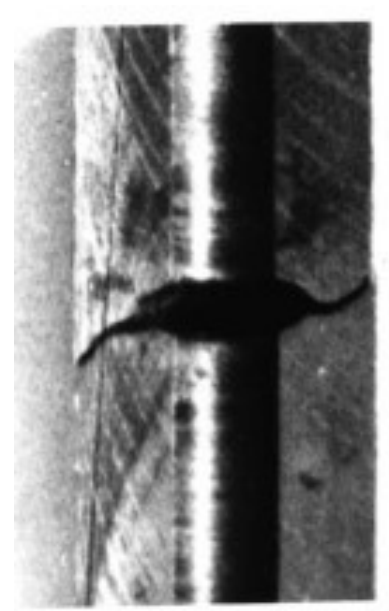

б)

Рисунок 5 - Характер зносу електродів зі сталі при їх відносному зсуві

Теплоту заліза, яка витрачається на його нагрівання при переведенні від початкового стану $\left(25^{\circ} \mathrm{C}\right)$ до кінцевого (температура кипіння), коли метал знаходиться в газоподібному стані знаходимо за виразом:

$$
\begin{gathered}
Q=\int_{298 K}^{1033 K} C_{p, \alpha}(T) d T+L_{\alpha \rightarrow \beta}+\int_{1033 K}^{1184 K} C_{p, \beta}(T) d T+L_{\beta \rightarrow \gamma}++\int_{1184 K}^{1674 K} C_{p, \gamma}(T) d T+L_{\gamma \rightarrow \delta} \\
+\int_{1674 K}^{1812 K} C_{p, \delta}(T) d T+L_{n l}++\int_{1812 K}^{3343 K} C_{p, p}(T) d T+L_{\beta}
\end{gathered}
$$

де $C_{p, \alpha}, C_{p, \beta}, C_{p, \gamma}, C_{p, \delta}, C_{p, p}$ - теплоємності, відповідно, твердого заліза у модифікаціях $\alpha, \beta, \gamma$ і $\delta$ та рідкого заліза;

$L_{\alpha \rightarrow \beta}, L_{\beta \rightarrow \gamma}, L_{\gamma \rightarrow \delta}-$ теплота відповідних фазових перетворень;

$L_{n л}, L_{\%}-$ теплота плавлення і випаровування.

Залежність теплоємності від температури характеризується рівнянням [10]:

$$
C_{p}=a+8 \cdot 10^{-3} T+C \cdot 10^{5} T^{-2} .
$$


Значення коефіцієнтів $\boldsymbol{a}, \boldsymbol{b}$ і $\boldsymbol{c}$, а також теплота фазових перетворень для заліза наведені у табл. 1 [10].

Таблиця 1 - Коефіцієнт температурної залежності теплоємності (Дж/2-am·K) та теплоти фазових перетворень заліза (Дж/2-ат)

\begin{tabular}{|c|c|c|c|c|c|}
\hline Модифікація заліза & $\boldsymbol{T}_{i, \boldsymbol{n}}-\boldsymbol{T}_{\boldsymbol{i}, \boldsymbol{\kappa}}$ & $\boldsymbol{a}_{\boldsymbol{i}}$ & $\boldsymbol{b}_{\boldsymbol{i}}$ & $\boldsymbol{C}_{\boldsymbol{i}}$ & $\boldsymbol{L}_{\boldsymbol{i}}$ \\
\hline$\alpha$ & $298 \ldots 1033$ & 4,18 & 5,92 & 0 & 2760 \\
\hline$\beta$ & $1033 \ldots 1184$ & 9,0 & 0 & 0 & 920 \\
\hline$\gamma$ & $1184 \ldots 1674$ & 1,84 & 4,66 & 0 & 880 \\
\hline$\delta$ & $1674 \ldots 1812$ & 10,5 & 0 & 0 & 15490 \\
\hline рiдке & $1812 \ldots 3343$ & 10,0 & 0 & 0 & 374300 \\
\hline
\end{tabular}

Після підстановки (4.2) в (4.1) та інтегрування отримуємо:

$Q=\sum_{i=1}^{5}\left\{\left(T_{i, \kappa}-T_{i, n}\right) \cdot\left[a_{i}+0,5 \cdot B_{i} \cdot 10^{-3}\left(T_{i, n}+T_{i, \kappa}\right)+C_{i} \cdot 10^{5} /\left(T_{i, n} \cdot T_{i, \kappa}\right)\right]+L_{i}\right\}$

де $\boldsymbol{i}$ - номер температурної ділянки; $T_{i, n}$ та $T_{i, \kappa}$ - початкова і кінцева температури на $\boldsymbol{i}$-тій ділянці.

Результати розрахунку за формулою (3) при використанні даних табл. 1 наведені у табл. 2 та на рис. 6.

Таблиця 2 - Залежність тепловмісту заліза від температури

\begin{tabular}{|c|c|c|c|c|c|c|c|c|}
\hline $\boldsymbol{T}, K$ & 298 & 500 & 700 & 900 & 1033 & 1033 & 1184 & 1184 \\
\hline $\boldsymbol{Q}$, Дж/2-am & 0 & 1322 & 2868 & 4651 & 5968 & 8728 & 10087 & 11007 \\
\hline & & & & & & & & \\
\hline
\end{tabular}

\begin{tabular}{|c|c|c|c|c|c|c|c|}
\hline $\boldsymbol{T}, \boldsymbol{K}$ & 1400 & 1674 & 1674 & 1812 & 1812 & 2000 & 2200 \\
\hline $\boldsymbol{Q}$, Дж/2-am & 12705 & 15172 & 16052 & 17500 & 32991 & 34871 & 36871 \\
\hline
\end{tabular}

\begin{tabular}{|c|c|c|c|c|c|c|c|}
\hline $\boldsymbol{T}, K$ & 2400 & 2600 & 2800 & 3000 & 3200 & 3343 & 3343 \\
\hline $\boldsymbol{Q}$, Дж/2-am & 38871 & 40871 & 42871 & 44871 & 46871 & 48301 & 422600 \\
\hline
\end{tabular}

При РОД, як зазначалось, електрична ерозія незалежно від струму відбувається в широкому діапазоні режимів, починаючи від розмірного плавлення $\mathrm{i}$ аж до тонкого розмірного випаровування. Тому джерела тепла на електродах за таких умов можуть бути охарактеризовані діапазонами температур $\boldsymbol{T}=1812 \ldots 3343 \mathrm{~K}$ i теплоти $\boldsymbol{Q}=32991 \ldots 422600$ Дж/2-am (рис. 6) відповідно при динамічних тисках потоку робочої рідини в межах $\boldsymbol{P}_{\boldsymbol{d}}=0,01 \ldots 0,5 M \Pi a$ (рис. 2). Це дозволяе, зокрема, оцінити питомі витрати електроенергії та продуктивність процесу, які відповідають експериментальним даним, а також використати отримані дані як вихідні для визначення функції температурного поля в зоні дії зазначених джерел тепла, що, в свою чергу, дозволяє оцінити величину зони термічного впливу при РОД.

Математичне формулювання задачі:

$$
\left\{\begin{array}{l}
\frac{\partial T}{\partial \tau}=a \frac{\partial^{2} T}{\partial x^{2}}, \quad 0 \leq x<\infty \\
T(0, \quad \tau)=T_{n} \\
T(x, \quad 0)=T_{o}, 0<x<\infty
\end{array}\right.
$$

де $\boldsymbol{T}_{\boldsymbol{n}}$ i $\boldsymbol{T}_{\boldsymbol{o}}$ - температура поверхні і початкова температура;

$a=6,7 \cdot 10^{-6}{ }^{2} / c-$ коефіцієнт температуропровідності [11]. 


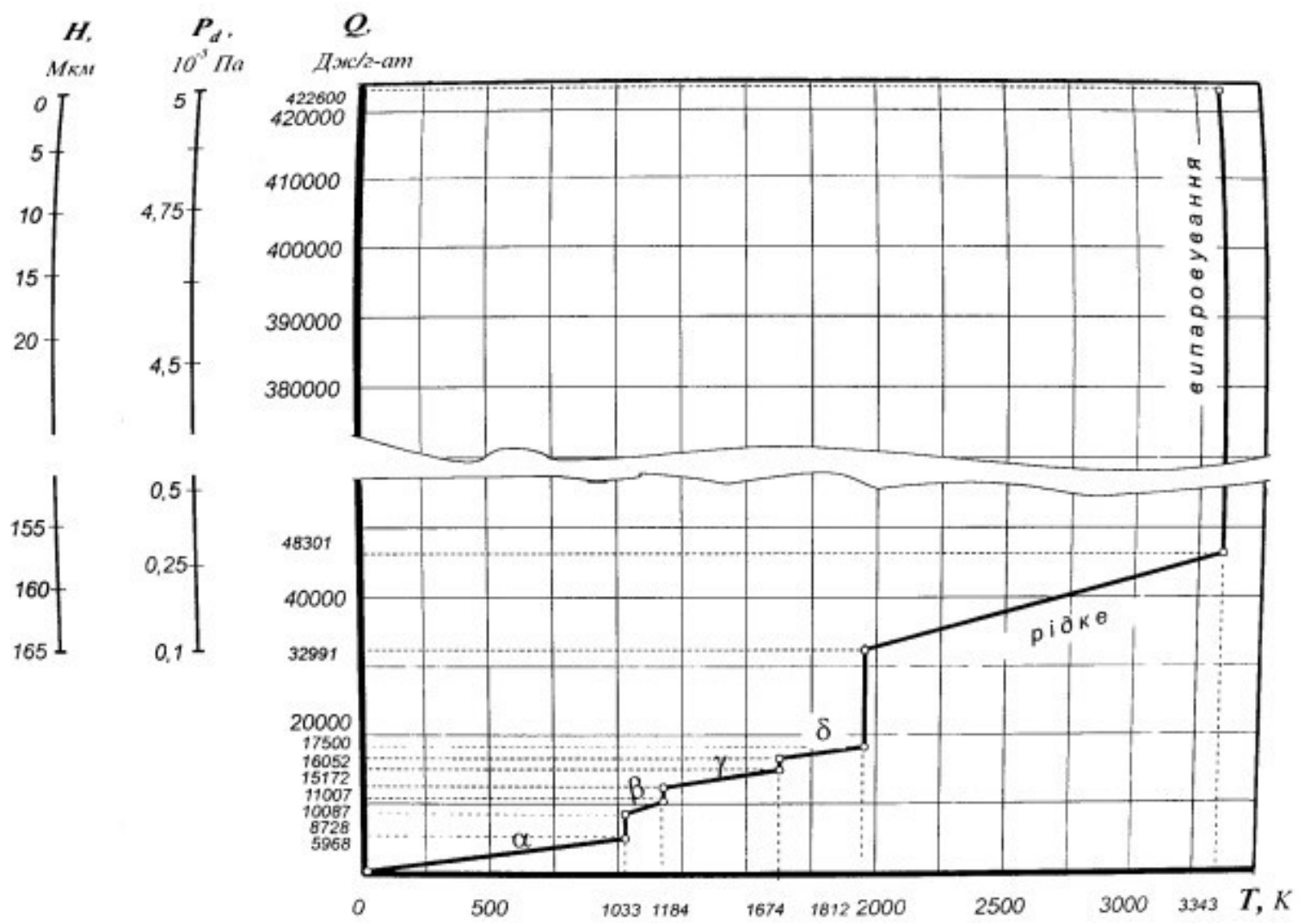

Рисунок 6 - Якісні характеристики джерел тепла на сталевих електродах

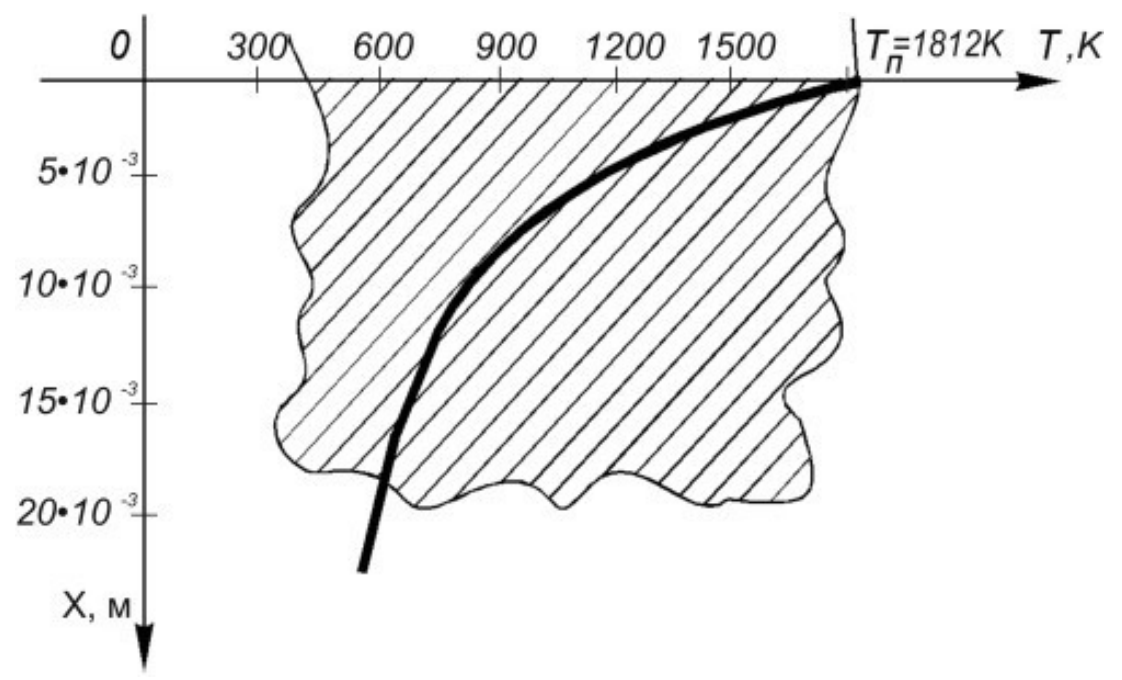

Рисунок 7 - Температурне поле в зоні дії джерела тепла

Розв 'язок задачі (4) є відомим [11]:

$$
\Theta=\frac{T_{n}-T}{T_{n}-T_{o}}=\frac{2}{\sqrt{\pi}} \int_{U=0}^{U_{k}} e^{-U^{2}} d U,
$$

де $U$ - комплексна безрозмірна змінна, яка визначається заданими значеннями параметрів $\boldsymbol{x}$ і $\tau$.

$$
U=x /(2 \sqrt{a \cdot \tau}) .
$$

Визначимо за допомогою рівнянь (5) і (6) глибину зони термічного впливу згідно зазначених умов при $\tau=0,005 \mathrm{c}$ при $T_{n}=T_{n л}=1812 \mathrm{~K}, T_{o}=303 \mathrm{~K}$, і $T=1073 \mathrm{~K}$. При 
цьому $\Theta=0,4762 ; U=0,451$ [12]. В підсумку отримуємо:

$$
x=U \cdot 2 \sqrt{a \cdot \tau}=1,65 \cdot 10^{-4} \mathrm{M} .
$$

Одержане значення $\boldsymbol{x}$ відповідає експериментальному (рис. 2) при динамічному тиску потоку рідини в зоні обробки $P_{d}=10^{4}$ Па та дозволяє приблизно визначити глибину зони термічного впливу $\boldsymbol{H}$ згідно зазначених умов при динамічному тиску потоку в межах $P_{d}=0,01 \ldots 0,5 \mathrm{MПа} \mathrm{(рис.} \mathrm{6).}$

Висновки. Можливості та якісні і кількісні характеристики процесу РОД визначаються якісними характеристиками (якістю) джерел тепла на електродах, перш за все, об'ємною густиною теплової потужності. Остання, в свою чергу, визначається динамічним тиском потоку робочої рідини, а також, в відомих межах, полярністю електродів. В зв'язку з цим є можливим легко (за рахунок регулювання швидкості потоку робочої рідини) керувати якістю джерел тепла на електродах, а отже і якістю процесу ерозії, здійснюючи обробку незалежно від струму в широкому діапазоні режимів, починаючи від грубого розмірного плавлення і аж до превалюючого тонкого розмірного випаровування.

Фізичний процес електричної ерозії при РОД характеризується безперервним підведенням енергії в зону обробки, безперервним горінням дуги і безперервним існуванням джерел тепла на електродах. Отже безперервною є теплова дія розряду на електроди і безперервно проходить процес ерозії.

Описано згідно існуючих уявлень в області фізики теплових процесів деякі якісні характеристики джерел тепла на електродах в умовах РОД та їх відповідність експериментальним даним для електродів із заліза та сталей.

\section{Список літератури}

1. Мазель А.Г. Технологические свойства электросварочной дуги [Текст] / А.Г. Мазель - М.: Машиностроение, 1969. - 178 с.

2. Кесаев И. Г. Катодные процессы электрической дуги [Текст] / И. Г. Кесаев - М.: Наука, 1968. $244 \mathrm{c}$.

3. Самервилл, Дж. М. Электрическая дуга [Текст] / Пер. с англ. К. Л. Гребень; Под ред. Л. Ю. Абрамовича. - Москва ; Ленинград : Госэнергоиздат, 1962. - 120 с.

4. Эккер Г. Современное развитие теории приэлектродных областей электрической дуги [Текст] / Г. Эккер // Теплофизика высоких температур. - 1973. - Т.2. - вып.4. - С. 865-870.

5. Носуленко В. І. Про якість джерел тепла на електродах і полярність електричної ерозії при РОД [Текст] / В.І. Носуленко // Збірник наукових праць КІСХМ. - 1998. - Вип 2. - С. 141-147.

6. Носуленко В. І. Розмірна обробка металів електричною дугою [Текст] : Автореф. дис. д-ра техн. наук: 05.03.07. / В.І. Носуленко. - Кіровоградський держ. техн. ун-т. - К., 1999. - 32 с.

7. Носуленко В.И. Физико-технологические особенности и классификация способов электроразрядной обработки металлов [Текст] / В.И. Носуленко, В.Н.Шмельев // Научнотеоретический и практический журнал "Современный научный вестник". Серия "Технические науки. Современные информационные технологии". - №19 (215) -. Белгород. - 2014. - С. 56-62.

8. Носуленко В.И. О качестве источников тепла на электродах в условиях процесса размерной обработки электрической дугой [Текст] / В.И. Носуленко, В.Н.Шмельев // Научно-теоретический и практический журнал "Оралдын гылым жаршысы". Серия "Технические науки. Физика. Современные информационные технологии". - № 8 (87) -. Казахстан - 2014. С. 61-68.

9. Идельчик И. Е. Справочник по гидравлическим сопротивлениям [Текст] / Под ред. М. О. Штейнберга. - 3-е изд., перераб. и доп. - М.: Машиностроение, 1992. - 672 с.

10. Солонин Н. С. Математическая статистика в технологии машиностроения [Текст] / Н. В. Солонин - М.: Машиностроение, 1972. - 216 с.

11. Сергеев Н. В. Плотность тока электродных пятен дуги с металлическими электродами [Текст] / Н. В. Сергеев, Г. А. Шепель // Журнал инженерной физики. - 1969. - Т.17. - №6. - С. 1041-1049.

12. Кесаев И. Г. Катодные процессы ртутной дуги и вопросы её устойчивости [Текст] / И. Г. Кесаев // Труды ВЭИ. - 1961. - Вып. 67. - С. 312-316. 


\section{References}

1. Mazel, A.G. (1969). Tekhnologicheskie svoystva elektrosvarochnoy dugi [Technological properties of electric-welding arc]. Moskow: Mashinostroenie.

2. Kesaev, I. G. (1968). Katodnye protsessy elektricheskoy dugi [Cathodic processes of an electric arc]. Moskow: Nauka.

3. Samervill, Dzh. M. (1962). Electric arc. L. Yu. Abramovicha (Ed.). (K. L. Greben, Trans). Moskow; Leningrad: Gosenergoizdat.

4. Ekker, G. (1973). Sovremennoe razvitie teorii prielektrodnykh oblastey elektricheskoy dugi [Modern development of the theory of near-electrode regions of the electric arc]. Teplofizika vysokikh temperatur - Thermal physics of high temperatures, Vol. 2, 4, 865-870.

5. Nosulenko, V. I. (1998). Pro jakistj dzherel tepla na elektrodakh i poljarnistj elektrychnoji eroziji pry ROD [On the quality of heat sources on the electrodes and the polarity of electric erosion with dimensional arc machining]. Zbirnyk naukovykh pracj KISHM - Collection of scientific works of the Kirovograd Institute of Agricultural Engineering, 2, 141-147.

6. Nosulenko, V. I. (1999). Rozmirna obrobka metaliv elektrychnoju dughoju [Size machining of metals by electric arc]. Extended abstract of Doctor's thesis. Kyiv.

7. Nosulenko, V.I. \& Shmelev, V.N. (2014). Fiziko-tekhnologicheskie osobennosti i klassifikatsiya sposobov elektrorazryadnoy obrabotki metallov [Physical Technological features and classification of methods of electric discharge processing of metals]. Nauchno-teoreticheskiy i prakticheskiy zhurnal "Sovremennyy nauchnyy vestnik". Seriya "Tekhnicheskie nauki. Sovremennye informatsionnye tekhnologii" - Scientific-theoretical and practical journal "The modern scientific bulletin". A series of "Technical Sciences. Modern Information Technologies" , 19 (215, 56-62.

8. Nosulenko, V.I. \& Shmelev, V.N. (2014). O kachestve istochnikov tepla na elektrodakh v usloviyakh protsessa razmernoy obrabotki elektricheskoy dugoy [On the quality of heat sources at the electrodes under the conditions of dimensional processing the electric arc]. Nauchno-teoreticheskiy i prakticheskiy zhurnal "Oraldyn gylym zharshysy". Seriya "Tekhnicheskie nauki. Fizika. Sovremennye informatsionnye tekhnologii". "Oral kalasi" - Scientific-theoretical and practical journal "Scientific-research organization". A series of "Technical Sciences. Physics and Modern Information Technologies", № 8 (87), 61-68.

9. Idelchik, I. Ye. (1992). Reference book on hydraulic resistance. (M. O. Shteynberga Ed.). (3d ed.). Moskow: Mashinostroenie.

10. Solonin, N. S. (1972). Matematicheskaya statistika v tekhnologii mashinostroeniya [Mathematical statistics in technology of mechanical engineering]. Moskow: Mashinostroenie.

11. Sergeev, N. V. \& Shepel, G. A. (1969). Plotnost toka elektrodnykh pyaten dugi s metallicheskimi elektrodami [Current density of electrode spots arc with metal electrodes]. Zhurnal inzhenernoy fizikiJournal of Engineering Physics, Vol.17, 6, 1041-1049.

12. Kesaev, I. G. (1961). Katodnye protsessy rtutnoy dugi i voprosy ee ustoychivosti [Cathode processes of mercury arc and problems its stability]. Trudy VEI - Treatise of the All-Union Electrotechnical Institute, $67,312-316$.

Victor Nosulenko, Prof., DSc., Vitaliy Shmelyov, Assos. Prof., PhD tech. sci.

Centralukrainian National Technical University, Kropivnitsky, Ukraine

\section{Qualitative Characteristics of Heat Sources on Steel Electrodes}

The electric arc is considered as the sum of three independently operating heat sources at the cathode, anode and arc column. At the same time, the qualitative characteristics (quality) of the heat source at the cathode determine the possibility and the qualitative side of the cathode erosion process, and the qualitative characteristics (quality) of the heat sources at the anode are the possibility and the qualitative side of the anode erosion process (treatment). Comparative quantitative and qualitative estimates of heat sources at the cathode and anode, in turn, allow us to draw conclusions about the polarity of electrical erosion, since, as is known, the effect of electric erosion is polar, that is, both quantitatively and qualitatively the erosion of the cathode and anode differ.

Create a reliable energy balance for the cathode region and separately for the anode region of the arc, that is, to give a quantitative and qualitative characterization of heat sources separately at the anode and separately at the cathode, using existing classical concepts of elementary processes in the arc, at the present time is impossible. The quality of the heat sources on the electrodes is described by the volume density of thermal power in the cathode and anode heat sources, which, in turn, is determined by the current density and the electric field strength, respectively, in the cathode and anode regions of the arc.

The qualities and qualitative and quantitative characteristics of the process of dimensional processing by an electric arc are determined by the qualitative characteristics (quality) of the heat sources on the electrodes, 
first of all, by the volume density of the thermal power. The latter, in turn, is determined by the dynamic pressure of the flow of the working fluid, as well as, in certain limits, by the polarity of the electrodes. In this connection, it is possible to easily control the quality of the heat sources on the electrodes, and consequently the quality of the erosion process, performing processing irrespective of the current in a wide range of modes, beginning from rough sized melting and to prevailing thin dimensional evaporation.

The physical process of electric erosion during dimensional processing by electric arc is characterized by a continuous supply of energy to the treatment zone, continuous burning of the arc and the continuous existence of heat sources at the electrodes. So the thermal effect of the discharge on the electrodes is continuous and the process of erosion is continuously proceeding.

Described according to the existing ideas in the field of the physics of thermal processes, some qualitative characteristics of heat sources on electrodes under conditions of dimensional processing by an electric arc and their correspondence to experimental data for electrodes from iron and steels.

electric arc, anode, cathode, arc column, source of heat, working fluid, current density

Одержано (Received) 06.06.2018

\section{УДК 621.179.14}

Olexsandr Mazheyka, prof., PhD tech. sci. Central Ukrainian national technical university, Kropyvnickiy, Ukraine E-mail: profkom551124@ukr.net

\section{Improved quality control of welded joints}

In this work, the magnetic field was reconfigured to control the suture. A computational model with a layout scheme for the horizontal and vertical magnetic fields of the seam bead with reference to the Cartesian coordinate system is proposed. The magnetic charges for a given welding roller are calculated. The topography of the defect field on the surface of the butt weld has been estimated. The results of the calculation of the tangential component of the field of convexity of the weld are obtained when the object is magnetized at an angle to the surface by the primary. The results of theoretical and experimental studies have shown high consistency, it is established that when the object is magnetized simultaneously perpendicular and parallel to its surface, the tangential component of the field The convexity of the seam is skew-symmetric, reminiscent of a sinusoid. The change in the convexity parameters of the weld does not change the field in the plane of its symmetry.

control, quality, object, welding compound, roller, topography, field, reliability, joint welding joint, defect, surface, magnet, Cartesian coordinate system

\section{А.И. Мажейка, проф., канд. техн. наук \\ Центральноукраинский национальный технический университет, г. Кропивницкий, Украина \\ Повышение контроля качества сварных соединений}

В работе проведено перестроение магнитного поля для контроля сварочного шва. Предложена расчетная модель со схемой расположения горизонтального и вертикального магнитных полей валика шва с привязкой к декартовой системе координат. Произведен расчет магнитных зарядов для заданного сварочного валика. Оценена топография поля дефекта на поверхности стыкового сварного шва Получены результаты расчета тангенциальной составляющей поля выпуклости шва при намагничивании объекта под углом к поверхности первичным Результаты теоретических и экспериментальных исследований показали высокую согласованность, установлено, что когда объект намагничен одновременно перпендикулярно и параллельно его поверхности, тангенциальная составляющая поля выпуклости шва является кососимметричной, напоминающей синусоиду. Изменение параметров выпуклости шва не приводит к изменению поля в плоскости его симметрии.

контроль, качество, объект, сварочное соединение, валик, топография, поле, надежность, стыковой сварочный шов, дефект, поверхность, магнит, декартова система координат

(C) Olexsandr Mazheyka, 2018 